http://dx.doi.org/10.7197/223.v39i31705.347462

\title{
Tc-99m MDP uptake in soft tissue calcification in systemic scleroderma (Crest syndrome)
}

\section{Sistemik sklerodermada yumuşak doku kalsifikasyo= nunda Tc-99m MDP tutulumu}

\section{Fadime Demir ${ }^{1}$, Taner Erselcan², Bülent Turgut ${ }^{3}$, Zekiye Hasbek ${ }^{3}$, Ayşegül Özdal ${ }^{4}$, Perihan Kelkit ${ }^{5}$, Pelin Duman 6 , Sibel Berksoy Hayta ${ }^{7}$}

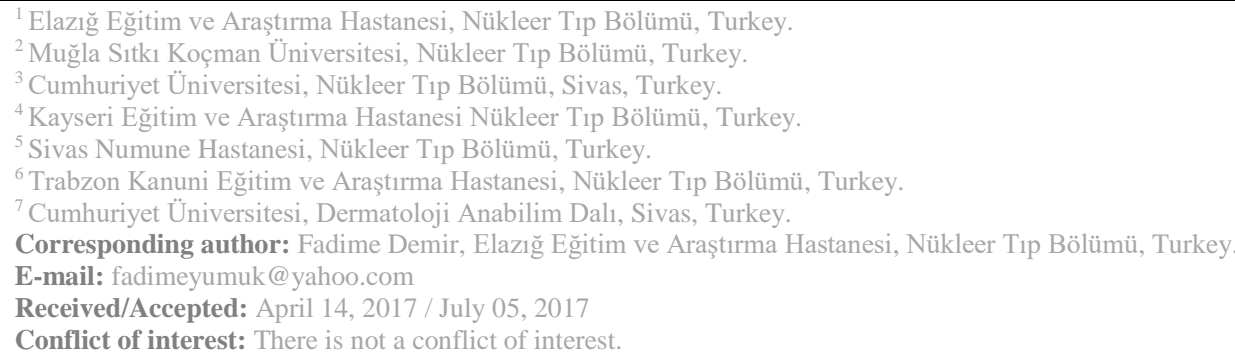

\section{SUMMARY}

23-year-old female patient was referred for evaluation of a 2-mounts history of discharge from the wound at the right gluteal region with three-phase Tc-99m MDP bone scintigraphy. The patient was diagnosed with scleroderma (SSc) five years ago. A three-phase bone scan performed after intravenous injection of $20 \mathrm{mCi} \mathrm{Tc}-99 \mathrm{~m}-\mathrm{MDP}$, in early blood pool of blood supply period, matching the right gluteal region showed findings consistent with perfusion and hyperemia In 3 . $\mathrm{Hr}$ after late images three-phase bone scan increased radiopharmaceutical uptake was observed in both the knee region extending from the region proximal to the pelvic soft tissue. When assessed, calcification at soft-tissue in bilateral knees was seen in the patient' $s$ direct radiography of the both knees. Our goal in presenting this case is to demonstrate the contribution of bone scintigraphy to the detection of calcinosis in patients with scleroderma and to determine the prevalence of it in the body.

Keywords: Systemic scleroderma, Tc-99m MDP, soft tissue calcification

\section{ÖZET}

23 yaşındaki bayan hasta, sağ gluteal bölgede ve uyluk lateralinde yer alan akıntılı yara şikayetleri üzerine, osteomyelit ön tanısı ile tüm vücut kemik sintigrafisi içinkliniğimize gönderildi. Hasta beş yıl önce Skleroderma tanısı almıştı. 20 mCi Tc-99m-MDP nin iv. Enjeksiyonu sonrası yapılan üç fazlı kemik sintigrafisinde; sağ gluteal bölgede perfüzyon artışı ve hiperemi ile uyumlu bulgular izlendi. Tc-99m MDP Üç fazlı kemik sintigrafisi 3. Saat geç görüntülerinde her iki diz bölgesi proksimalinde olmak üzere pelvik bölgeye uzanan yumuşak dokuya uyan alanda artmış radyofarmasötik tutulumu izlenmiştir. Hastanın direk radyografi görüntülerinde aynı alanlarda yumuşak doku kalsifikasyonu ile uyumlu görünüm izlendi. Hastanın direk radyografi görüntüleri incelendiğinde her iki diz bölgesinde yumuşak doku kalsifikasyonu ile uyumlu görünüm izlendi. Bu vakayı sunmaktaki amacımız, kemik sintigrafisinin sklerodermalı hastalardaki kalsinozisi göstermede ve vücuttaki yaygınlığının saptanmasındaki katkısını göstermektir. 


\section{INTRODUCTION}

Systemic sclerosis (SSc) is a connective tissue disease characterised by vascular, immune, and fibrotic changes in the skin and some internal organs. ${ }^{1}$

Calcinosis is one of the typical manifestations of CREST syndrome. The other features include Raynaud's phenomenon, esophageal dysmotility, sclerodactyly and telangiectasia The calcinosis results from deposition of amorphous calcium hydroxyapatite crystals in the skin, soft tissue or muscles. Local or systemic inflammatory factors are thought to mediate calcium precipitation. Superinfection can occur and often requires antibiotics and surgical débridement. ${ }^{2}$

SSc calcinosis may be palpable on exam and/or diagnosed by imaging.Plain X-rays are useful to confirm location of calcinosis and could be used to estimate the area of some of these deposits, whereas ultrasound and computed tomography (CT) are more helpful in showing the location of these deposits in the soft tissues. ${ }^{3}$

Bone scintigraphy is performed using Tc-99mlabeled diphosphates ((Methylene diphosphonate (MDP) and hydroxy methylene diphosphonate (HMDP)). It is thought that the phosphate compounds are absorbed by the chemical bonds present in the hydroxyapatite on the bone surface and that Tc-99m is released and bound to the bone. ${ }^{4}$

Since the introduction of the $99 \mathrm{~m}-\mathrm{Tc}$-phosphate compounds, unusual extraosseous accumulations have been reported, in which chemiadsorption into the hydroxyapatite crstals is the proposed

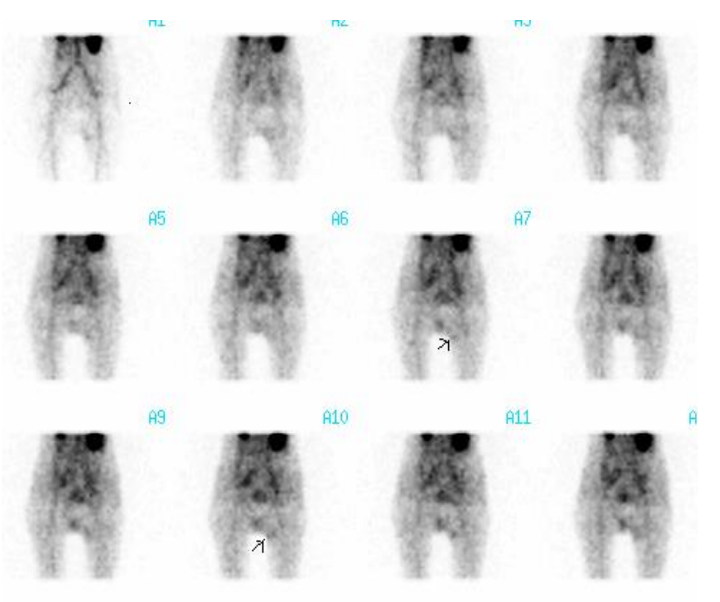

Figure 1. Posterior perfusion image. Increased radiopharmaceutical accumulation is seen at right gluteal region. mechanism of uptake. $^{5}$ Scintigraphy with technetium-99m methylene diphosphonate (MDP) delineates a wide spectrum of nonosseous disorders. Neoplastic, hormonal, inflammatory, ischemic, traumatic, excretory, and artifactual entities demonstrate abnormal soft-tissue uptake of Tc-99m MDP. Mechanisms leading to increased extraosseous Tc-99m MDP uptake include extracellular fluid expansion, enhanced regional vascularity and permeability, and elevated tissue calcium concentration. ${ }^{6}$

Our goal in presenting this case is to demonstrate the contribution of bone scintigraphy to the detection of calcinosis in patients with scleroderma and to determine the prevalence of it in the body.

\section{CASE REPORT}

23-year-old female patient was referred for evaluation of a 2-mounts history of discharge from the wound at the right gluteal region with threephase Tc-99m MDP bone scintigraphy. The patient was diagnosed with SSc five years ago. The patient's findings consisted pain and swelling at joint, erythema at eyelid, difficulty swallowing, weight loss for five years. PUVA therapy and colchicine was given after the diagnosis.

A three-phase bone scan performed after intravenous injection of $20 \mathrm{mCi} \mathrm{Tc}-99 \mathrm{~m}-\mathrm{MDP}$, in early blood pool of blood supply period, matching the right gluteal region showed findings consistent with perfusion and hyperemia (Fig. 1,2), in 3 . Hr after late images as unusual increased radiopharmaceutical uptake was observed in both the knee region extending from the region proximal to the pelvic soft tissue. (fig. 3,4).

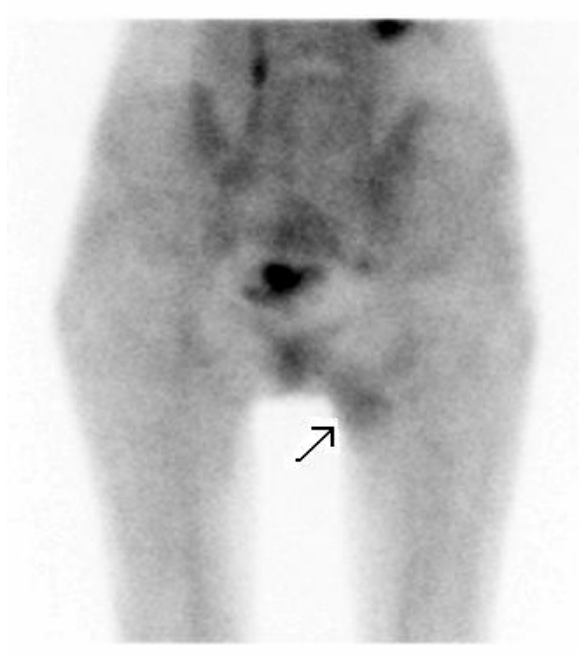

Figure 2. Posterior early blood pool image. Increased radiopharmaceutical accumulation is seen at right gluteal region. 


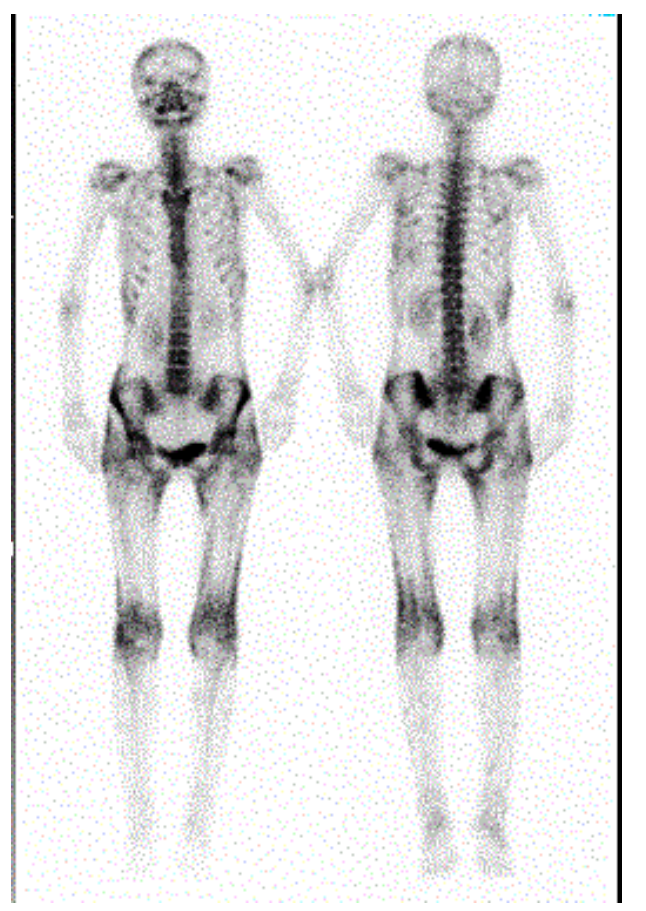

Figure 3. Increased radiopharmaceutical uptake was observed in both the knee region extending from the region proximal to the pelvic soft tissue.

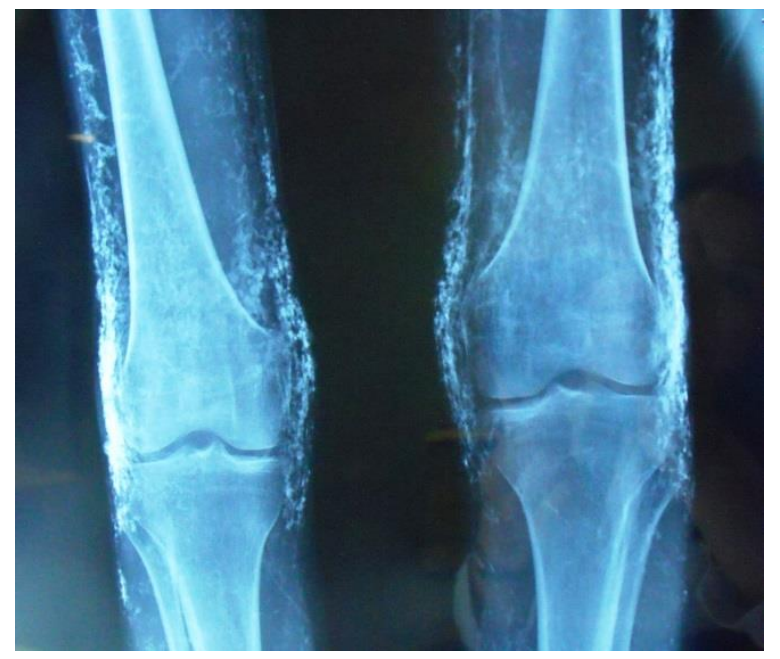

Figure 5. Radiograph of both the knee region shows the calcification at soft tissue.
When assessed, calcification at soft-tissue in bilateral knees (fig. 5) was seen in the patient' s direct radiography of the both knees.

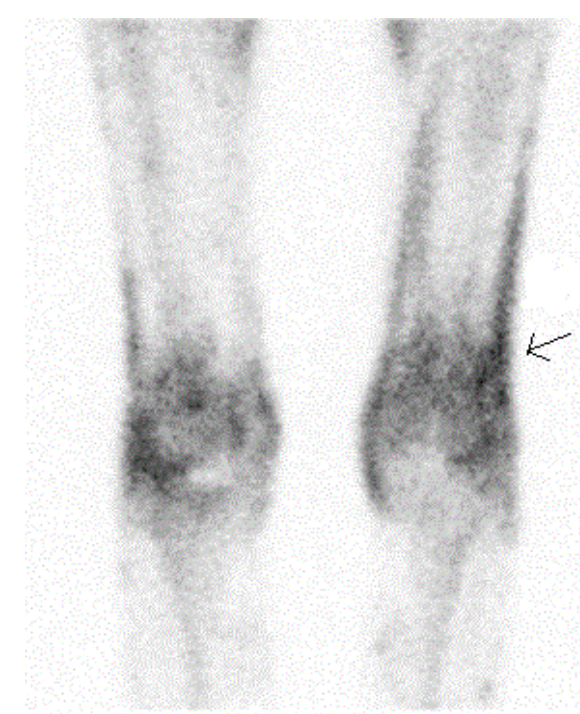

Figure 4. Anterior bone scan. Increased uptake was observed in the soft tissue of both the knee region.

\section{DISCUSSION}

Calcinosis, especially calcinosis cutis, is classified into four clinical types: dystrophic, idiopathic, tumoral and metastatic. Dystrophic calcinosis occurs in up to $10 \%$ of patients with SSc. Calcification may be seen in the skin and subcutaneous tissue, but rarely in tendons and muscles. ${ }^{7}$ The mechanism for calcinosis in SSc and other collagen diseases is poorly understood. Local tissue factors are probably more important than any systemic derangement in the calcium or phosphorus balance. ${ }^{8}$

Serum calcium and phosphorus levels are in normal ranges in our patient (serum calcium, 9,7 $\mathrm{mg} / \mathrm{dL}$ and phosphate, $4,6 \mathrm{mg} / \mathrm{dL}$ ).

In 3 hours, Tc-99m MDP concentration in normal tissues is proportional to their calcium content, ranging from a low concentration in muscle ( $0.005 \%$ calcium) to a high one in bone (14\%-24\% calcium). Extraosseous bone-producing disorder shaves an affinity for Tc-99m MDP like that of normal bone. Current evidence indicates that MDP acts as a ligand adsorbing onto tissue calcium, localizing the Tc-99m in the mineral phase with no significant organic substrate interaction. ${ }^{6}$

Radiological examinations including plain film xray, CT scanning and bone scintigraphy are useful in demonstrating the extent of tissue calcification. In literature, it has been reported in a number of 
extraosseous calcification in SSc as assessed by $\mathrm{x}$ ray and CT. But the whole body scan may be useful to evaluate all soft tissue in the body at the same time.

Our experience suggests that the whole body scan can be used for demonstrating the soft tissue calcification in the disease causing calcification at soft tissue with correlative anatomical imaging.

\section{REFERENCES}

1. Avouac J, Guerini H, Wipff J, Assous N, Chevrot A, Kahan A et al. Radiological hand involvement in systemic sclerosis, Ann Rheum Dis 2006;65(8):1088-1092. doi: 10.1136/ard.2005.044602.

2. Tangri* N and Young BM. Soft-tissue infection and underlying calcinosis of CREST syndrome. CMAJ. 2006 October 24; 175(9): 1059,1061 .

3. Hsu V, Bramwit M and Schlesinger N. Use of dual-energy computed tomography for the evaluation of calcinosis in patients with systemic sclerosis. Clin Rheumatol (2015) 34:1557-1561.
4. Ömür Ö, Kapulu C, Uğur Ö. Kas İskelet Sistemi Hastalıklarında Nükleer Tıp Yöntemleri. Türk Ortopedi ve Travmatoloji Birliği Derneği Dergisi 2007; 6 :1-2 .

5. Hwang GJ, Lee JD,Park CY and Lim SK. Reversible Extras- keletal Uptake of Bone Scanning in Primary Hyperparathyroidism. J Nucl Med 1996;37(3):469-471.

6. Peller PJ,Ho VB, Kransdorf MJ. Extraosseous Tc-99m MDP Uptake. A Pathophysiologic Approach1. RadioGraphics 1993; 13(4):715734.

7. Jinnin M, Ihn H, Asano Y, Yamane K, Yazawa N, Tamaki K. A case of linea scleroderma with muscle calcification. British Journal of Dermatology 2002; 146(6): 1084-1086.

8. Schlenker JD, Clark DD and Weckesser EC. Calcinosis Circum- scripta of the Hand in Scleroderma. J Bone Joint Surg Am. 1973;55(5):1051-1056. 